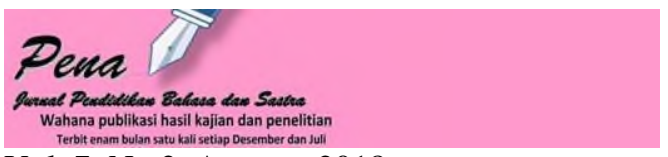

Vol. 7, No.2, Agustus 2018,

P-ISSN: 2089-3973, E-ISSN: 2615-7705

DOI: https://doi.org/10.22437/pena.v7i2.5742

\title{
Pengembangan Materi Keterampilan Mengajar Berbasis Problem Based Learning untuk Meningkatkan Kompetensi Pedagogik Mahasiswa
}

\author{
Imam Suwardi Wibowo ${ }^{1}$, Panut Setiono ${ }^{2}$ \\ PBSI FKIP Universitas Jambi ${ }^{1}$, PGSD FKIP Universitas Jambi ${ }^{2}$ \\ imamsuwardi.wibowo@yahoo.com ${ }^{1}$, maspanutsetiono@gmail.com ${ }^{2}$
}

\begin{abstract}
Abstrak
Penelitian ini bertujuan untuk memperoleh kevalidan, kepraktisan dan kemenarikan untuk produk pengembangan materi keterampilan mengajar berbasis Problem Based Learning untuk meningkatkan kompetensi pedagogik mahasiswa Program Studi Pendidikan Bahasa dan Sastra Indonesia Fakultas Keguruan dan Ilmu Pendidikan Universitas Jambi yang disusun kedalam bentuk modul belajar. Langkah-langkah yang dilakukan dalam penelitian ini mengikuti langkah-langkah Model Dick, Carrey \& Carrey (2009) yang disederhanakan menjadi sembilan dari sepuluh langkah yang ada. Instrumen yang digunakan dalam penelitian ini yaitu angket validasi ahli angket kepraktisan dari teman sejawat dan uji kemenarikan dari mahasiswa. Dari hasil uji kelayakan produk pengembangan pada hasil uji validasi ahli mendapat skor presentase sebesar 84,62\%, produk yang sudah dikembangkan sangat layak untuk digunakan. Uji kepraktisan berdasarkan hasil tanggapan dosen terhadap modul belajar sebesar 91,2 \%, produk yang dikembangkan masuk dalan kategori kriteria digunakan tanpa revisi. Pada uji kepraktisan melalui tanggapan perserta didik diperoleh hasil dengan presentase rata-rata sebesar $75,16 \%$, hasil ini berada pada tingkat kualifikasi layak.
\end{abstract}

Kata Kunci: problem based learning, kompetensi pedagogik

\begin{abstract}
This study aims to obtain validity, practicality and attractiveness for the development of teaching skills based on Problem Based Learning materials to improve the pedagogical competence of students of the Jambi University Language and Literature Education Study Program at the University of Jambi which is organized into learning modules. The steps taken in this study follow the steps of Model Dick, Carrey \& Carrey (2009) which are simplified into nine of the ten steps. The instruments used in this study were expert validation questionnaires from practical questionnaires from peers and tests of student interest. From the results of the product development feasibility test on the results of the expert validation test got a percentage score of $84.62 \%$, the products that have been developed are very feasible to use. Practicality test based on the results of the lecturers' responses to the learning module was $91.2 \%$, the products developed in the criteria category were used without revision. In the practicality test through student responses obtained results with an average percentage of $75.16 \%$, these results are at the level of eligibility.
\end{abstract}

Keywords: problem based learning, pedagogic competence 


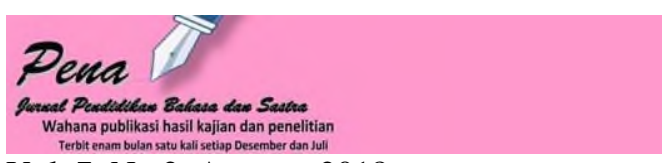

Vol. 7, No.2, Agustus 2018,

P-ISSN: 2089-3973, E-ISSN: 2615-7705

DOI: https://doi.org/10.22437/pena.v7i2.5742

\section{PENDAHULUAN}

Keberhasilan proses pendidikan nasional tidak terlepas dari peran seorang guru yang menjalankan tugas profesionalnya. Hal ini dikarenakan, seorang guru tidak hanya berupaya menjalankan tugas pekerjaan sesuai dengan profesinya, tetapi lebih dari itu guru juga berupaya mengembangkan kompetensi peserta didik berupa pengembangan kemampuan dan membentuk watak serta peradaban bangsa yang bermartabat dalam rangka mencerdaskan kehidupan bangsa, bertujuan untuk mengembangkan potensi peserta didik agar menjadi manusia yang beriman dan bertaqwa, sehat, berilmu, cakap, kreatif, mandiri, dan menjadi warga negara yang demokratis serta bertanggungjawab.

Dalam Undang-Undang Republik Indonesia Nomor 14 Tahun 2005 Tentang Guru dan Dosen Pasal 1 Ayat 1 disebutkan bahwa guru adalah pendidik profesional dengan tugas utama mendidik, mengajar, membimbing, mengarahkan, melatih, menilai, dan mengevaluasi peserta didik pada pendidikan anak usia dini jalur pendidikan formal, pendidikan dasar, dan pendidikan menengah. Profesionalisme guru harus didukung oleh kompetensi standar yang harus dikuasai oleh para guru professional.

Dewasa ini permasalahan kualitas guru banyak dipertanyakan, hal ini dikarenakan rendahnya mutu pendidikan di Indonesia. Sebagai contoh, dari hasil studi internasional yang dilakukan oleh Trends in International Mathematics and Science Study (TIMSS) pada siswa kelas VII SMP pada tahun 2011, peringkat Indonesia berada di angka 38 dari 45 negara yang disurvey. (Kemdikbud, 2017). Demikian juga hasil tes yang dilakukan PISA menyatakan bahwa dalam Indonesia berada pada peringkat 64 dari 65 peserta negara yang mengikuti tes tesebut dalam bidang literasi di bidang membaca, matematika dan sains.

Kualitas guru yang berada di bawah standar dirasa belum mampu untuk memperbaiki mutu pendidikan di Indonesia. Hal ini dikarenakan profesi guru merupakan profesi yang mudah dan dapat dilakukan oleh siapa saja. Wajar saja jika kemudian, mantan Menteri Pendidikan Nasional Wardiman Djoyonegoro mengungkapkan bahwa "saat ini, hanya 43\% saja guru di Indonesia yang memenuhi syarat dalam melaksanakan tugas-tugasnya. Artinya ada sekitar 57\% tidak atau belum memenuhi syarat, tidak kompeten dan tidak profesional. Pantas saja kalau kualitas pendidikan kita jauh dari harapan dan kebutuhan”. 


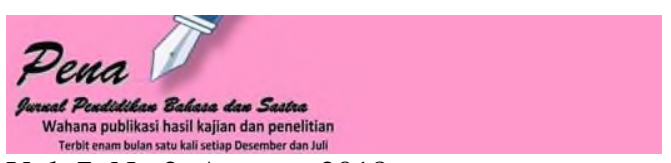

Vol. 7, No.2, Agustus 2018,

P-ISSN: 2089-3973, E-ISSN: 2615-7705

DOI: https://doi.org/10.22437/pena.v7i2.5742

Untuk dapat melaksanakan tugasnya, guru harus memiliki salah satu keterampilan dasar mengajar yang memadai. Permendiknas Nomor 16 Tahun 2007 tentang Standar Kualifikasi Akademik dan Kompetensi Guru disebutkan bahwa dalam melaksanakan tugas profesinya guru harus memiliki kompetensi pedagogik, kompetensi professional, kompetensi sosial, dan kompetensi kepribadian. Dalam melaksanakan tugas pengajaran kepada peserta didik, hendaklah guru memiliki kompetensi pedagogik yang meliputi diantaranya kegiatan pembelajaran yang mendidik, pengembangan potensi peserta didik, komunikasi dengan peserta didik.

Untuk menunjang kompetensi pedagogik, maka seorang guru perlu memahami memiliki delapan keterampilan dasar mengajar. Dari hasil penelitian yang dilaksanakan oleh penelitian (Sri Anitah, 2009:7.21), terdapat 8 keterampilan dasar mengajar yang dianggap berperan penting dalam menentukan keberhasilan pembelajaran. Delapan keterampilan ini antara lain: 1) keterampilan bertanya dasar dan lanjut, 2) keterampilan menjelaskan, 3) keterampilan memberi penguatan, 4) keterampilan menggunakan variasi, 5) keterampilan membuka dan menutup pelajaran, 6) keterampilan mengajar kelompok kecil dan perorangan, 7) keterampilan mengelola kelas, dan 8) keterampilan membimbing diskusi kelompok kecil.

Permasalahan yang terjadi saat ini adalah kurangnya ketersediaan sumber-sumber belajar untuk mengembangkan kemampuan keterampilan dasar mengajar secara teoritis yang sesuai dengan kebutuhan mahasiswa calon guru. Jikapun ada maka jumlahnya terbatas dan memiliki tingkat adaptasi yang lemah. Hal ini dikarenakan materi-materi keterampilan dasar mengajar guru tersedia dalam beberapa buku-buku umum, tidak membahas secara khusus tentang keterampilan mengajar secara teoritis empiris. Idealnya, mahasiswa calon guru ini dapat mengakses sumber-sumber rujukan teoritis keterampilan mengajar dengan mudah dan murah. Sehingga dapat memaksimalkan kompetensi pedagogik mahasiswa calon guru dalam melaksanakan tugas dan kewajiban pengajaran di sekolah praktik.

Untuk mengatasi kesenjangan yang terjadi di atas, maka perlu dilakukan dengan mengembangkan materi keterampilan mengajar untuk meningkatkan kompetensi pedagogik mahasiswa calon guru yang mengikuti program PPL/PK. Nantinya materi ini akan disusun dalam bentuk sebuah modul pembelajaran. Dari hasil penelitian yang dilakukan oleh Sri Anitah (2009:72), terdapat 8 keterampilan dasar mengajar yang dianggap berperan penting dalam menentukan keberhasilan pembelajaran. Sehingga diharapkan calon guru ini tidak 


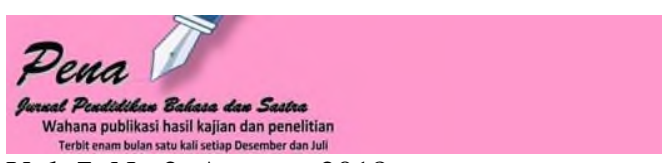

Vol. 7, No.2, Agustus 2018,

P-ISSN: 2089-3973, E-ISSN: 2615-7705

DOI: https://doi.org/10.22437/pena.v7i2.5742

hanya menguasai keterampilan mengajar saja, tetapi juga dapat membantu siswa dalam menuntaskan kegiatan pembelajaran.

Sebagaimana dijelaskan oleh Mulyasa (2007) meskipun setelah mengikuti program Praktik Pengalaman Lapangan mahasiswa calon guru lulus dengan perolehan nilai yang baik, namun beberapa tahun mengajar guru ini akan memiliki kelemahan - kelemahan seperti (1) dalam proses belajar-mengajar, guru kurang dapat menerapkan metode mengajar yang bervariasi dan kurang menguasai teknik bertanya, (2) guru kurang mampu mengontrol suasana kelas, (3) guru jarang menggunakan alat bantu mengajar, karena kurang mampu memilih alat bantu yang sesuai dengan materi pelajaran tertentu dan tingkat intelektual peserta didik, (4) guru kurang memberikan kesempatan kepada mahasiswa untuk bertanya, (5) guru mengalami kesulitan dalam menentukan mahasiswa yang sudah mengerti dan belum mengerti tentang materi yang telah diajarkan.

Salah satu yang dapat dilakukan untuk mengatasi kelemahan-kelemahan di atas, diantaranya membekali mahasiswa untuk melaksanakan praktik pengajaran secara mikro (microteaching) juga dapat dilakukan dengan menyediakan sumber rujukan yang dapat dijadikan sebagai sumber bacaan teoritis melaksanakan tugas pengajaran. Untuk itu, pegembangan modul belajar dirasa sebagai salah satu langkah tepat dalam mengatasi keterbatasan sumber rujukan teoritis empiris.

Diyakini bahwa pembelajaran bermodul secara efektif akan dapat mengubah konsepsi mahasiswa calon guru menuju konsep ilmiah, sehingga pada gilirannya hasil belajar mereka dapat ditingkatkan seoptimal mungkin baik dari segi kualitas maupun kuantitasnya. Hasil penelitian terdahulu Santyasa, dkk (1995, 1996, 1997, 1998, 1999) menyatakan bahwa penerapan modul dapat mengubah miskonsepsi siswa menjadi konsepsi ilmiah dan dapat meningkatkan hasil belajar siswa.

Dari uraian latar belakang masalah di atas, maka peneliti tertarik untuk mengadakan penelitian dan pengembangan dengan judul: Pengembangan Materi Keterampilan Mengajar Berbasis Problem Based Learning Untuk Meningkatkan Kompetensi Pedagogik Mahasiswa FKIP Universitas Jambi. Tujuan penelitian dan pengembangan ini yaitu (1) utnuk mengetahui prosedur penelitian dan pengembangan modul keterampilan mengajar Berbasis Problem Based Learning untuk meningkatkan kompetensi pedagogik mahasiswa Pendidikan Bahasa dan Sastra Indonesia Fakultas Keguruan dan Ilmu Pendidikan Universitas Jambi, (2) untuk 


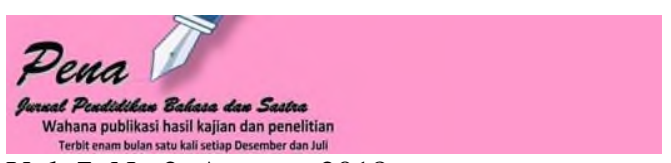

Vol. 7, No.2, Agustus 2018,

P-ISSN: 2089-3973, E-ISSN: 2615-7705

DOI: https://doi.org/10.22437/pena.v7i2.5742

mengetahui kevalidan, dan kepraktisan modul keterampilan mengajar Berbasis Problem Based Learning untuk meningkatkan kompetensi pedagogik mahasiswa Bahasa dan Sastra Indonesia Fakultas Keguruan dan Ilmu Pendidikan Universitas Jambi.

\section{KAJIAN PUSTAKA}

\section{Modul Pembelajaran}

Depdiknas (2008) mendefinisikan modul sebagai alat atau sarana pembelajaran yang berisi materi, metode, batasan-batasan, dan secara mengevaluasi yang dirancang secara sistematis dan menarik untuk mencapai kompetensi yang diharapkan sesuai dengan kompleksinya. Sedangkan Nasution (2003:205), mengemukakan modul dapat dirumuskan sebagai: suatu unit yang lengkap yang berdiri sendiri dan terdiri atas suatu rangkaian kegiatan belajar yang disusun untuk membantu siswa mencapai sejumlah tujuan yang dirumuskan secara khusus dan jelas

Modul pembelajaran yang disusun dengan baik dapat memberikan banyak keuntungan, yaitu: a) dapat meningkatkan pembelajaran secara maksimal, b) siswa lebih aktif dalam proses belajarnya karena menghadapi sejumlah masalah atau tugas yang harus dikerjakan, c) dapat memberika balikan dengan segera sehingga siswa dapat mengetahui hasil belajarnya, d) kegiatan siswa terarah, karena modul mengandung sasaran belajar yang jelas, dan e) keterlibatan guru dalam pembelajaran sangat minimal (Russel, 1974:20; Suryobroto, 1983:16; dan Nasution 2000:206).

Komponen yang harus ada di dalam modul sesuai Depdiknas (2008), komponen isi modul yang harus tersedia yaitu terdiri atas bagian pembuka (judul, daftar isi, peta informasi, daftar tujuan kompetensi, tes awal), bagian inti (tinjauan materi, hubungan dengan materi lain, uraian materi, penugasan, rangkuman), dan bagian akhir (glosarium, tes akhir, indeks).

Pengembangan materi keterampilan mengajar Berbasis Problem Based Learning untuk meningkatkan kompetensi pedagogik mahasiswa FKIP Universitas Jambi yang disusun ke dalam modul ini berdasarkan pendapat yang dikemukan oleh Severy (2006) yang menyatakan PBL dilaksanakan dengan pendekatan belajar yang berpusat pada siswa yang dapat memberdayakan siswa untuk melakukan penelitian, memadukan teori dan praktek, serta menerapkan pengetahuan dan ketrampilan untuk mengembangkan penyelesaian masalah. 


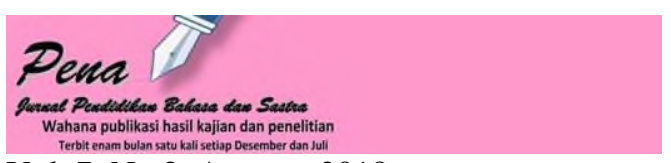

Vol. 7, No.2, Agustus 2018,

P-ISSN: 2089-3973, E-ISSN: 2615-7705

DOI: https://doi.org/10.22437/pena.v7i2.5742

\section{Kompetensi Pedagogik}

Kompetensi pedagogik adalah kemampuan mengelola pembelajaran mahasiswa yang meliputi pemahaman terhadap peserta didik, perancangan dan pelaksanakan pembelajaran, evaluasi hasil belajar, dan pengembangan mahasiswa untuk mengaktulisasikan berbagai potensi yang dimilikinya (Amin, Aunurrahman, Thamrin, 2015). Sedangkan menurut Payong (2011:29) kompetensi pedagogik ini juga berarti segala usaha yang dilakukan oleh pendidik untuk membimbing anak muda menjadi manusia dewasa dan matang. Kemampuan pedagogik ini erat sekali kaintannya dengan kemampuan dikdaktik dan metodik yang harus dimiliki oleh guru sehingga dia dapat berperan sebagai pendidik dan pembimbing yang baik.

Mulyasa (2011:79) dan Payong (2011:29) menyatakan kompetensi pedagogik sangat penting karena menjadi penentu bagi keberhasilan proses belajar yang langsung menyentuh kemampuan pembelajaran meliputi pengelolaan peserta didik, perencanaan, perencangan pelaksanaan, evaluasi hasil belajar dan pengembangan mahasiswa terhadap potensi yang dimilikinya 1) menguasai karakteristik mahasiswa 2) menguasai teori belajar 3) mengembangkan kurikulum 4) menyelenggarakan pembelajaran 5) memanfaatkan teknologi informasi 6) mengembangkan potensi mahasiswa 7) berkomunikasi secara efektif 8) melaksanakan penilaian 9) memanfaatkan hasil penilaian untuk kepentingan pembelajaran 10) melakukan tindakan reflektif'.

Kompetensi pedagogik ini sangat besar pengaruhnya terhadap keberhasilan suatu program pembelajaran yang dikelola di dalam kelas. Sebagaimna hasil penelitian yang dilakukan oleh Khofiatun, Sa'dun Akbar, M. Ramli (2016) menyatakan bahwa peran kompetensi pedagogik guru dalam proses pembelajaran juga berpengaruh terhadap hasil pembelajaran tematik dikelasnya. Guru yang memiliki kompetensi pedagogik bagus cenderung berhasil dalam pembelajaran tematik di kelasnya. Sedangkan guru yang memiliki kompetensi pedagogik rendah cenderung tidak berhasil dalam pembelajaran tematiknya kemampuan pada kompetesi pedagogik menjadi sangat penting karena juga berperan pada kinerja guru mengajar. Sergiovanni dalam Pupuh Fathurrohman (2012:32) mengatakan kinerja guru erat kaitannya dengan peningkatan pemberdayaan guru tersebut dimana guru harus dapat mengkritisi kurikulum secara mandiri, dapat mengelola kelas dan modul belajar nya serta dapat meningkatkan cara mengajarnya secara efisien. Hasil penelitian yang dilakukan oleh Amin, Aunurrahman, Thamrin, (2015) menyatakan dari hasil analisis korelasi 


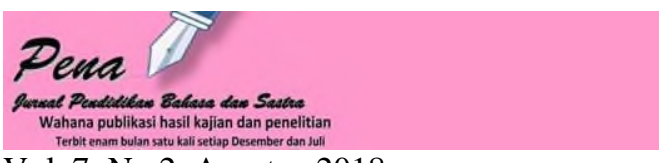

Vol. 7, No.2, Agustus 2018,

P-ISSN: 2089-3973, E-ISSN: 2615-7705

DOI: https://doi.org/10.22437/pena.v7i2.5742

sederhana juga dapat dibuktikan bahwa hubungan kompetensi pedagogik dan kinerja pembelajaran guru signifikan. Hal ini terbukti dari besaran angka signifikansi Sig. (2-tailed) antara variabel pedagogik dan kinerja pembelajaran guru lebih kecil dari 0,05 atau 0,000 < 0,05. Dengan demikian dapat disimpulkan bahwa ada hubungan yang signifikan antara kompetensi pedagogik dengan kinerja pembelajaran guru.

Dengan demikian dapat disimpulkan bahwa dalam penelitian ini kompetensi pedagogik merupakan kompetensi yang harus dimiliki oleh guru untuk mengelola dan melaksanakan pengembangan kurikulum terkecil dan mengelola pembelajaran di kelas. Kompetensi ini berperan terhadap hasil pembelajaran di kelas, semakin baik kompetensi pedagogik yang dimiliki oleh seorang guru maka hasil pembelajaran di kelas juga akan semakin baik. Di samping itu, kompetensi pedagogik yang memadai memiliki pengaruh yang signifikan terhadap kinerja guru.

\section{Tinjauan Mata Kuliah PPL/PK}

Pengalaman lapangan merupakan salah satu kegiatan intrakurikuler yang dilaksanakan oleh mahasiswa yang mencakup latihan mengajar maupun tugas-tugas kependidikan di luar mengajar secara terbimbing dan terpadu untuk memenuhi persayaratan pembentukan profesi kependidikan. Menurut Najjah (2014) Praktik Pengalaman Lapangan (PPL) adalah kegiatan belajar mahasiswa yang dilakukan di lapangan untuk mengintegrasikan pengetahuan teoritis yang diperoleh di kampus dengan pengalaman praktik di lapangan, sehingga target khusus yang merupakan target kompetensi program studi dapat tercapai.

Dalam buku pedoman PPL yang dikeluarkan oleh Unit Pelaksana Teknis (UPT) PPL Universitas Jambi menyebutkan bahwa Praktik pembelajaran adalah latihan melaksanakan kegiatan pembelajaran di sekolah oleh mahasiswa di dalam kelas, mulai dari membuat perencanaan pembelajaran (silabus dan RPP), pelaksanaan dan penilaian. Sedangkan praktik pengelolaan administrasi adalah latihan melaksanakan tugas-tugas administrasi, bimbingan dan lain-lain.

Mata kuliah ini memiliki bobot 4 SKS yang dilaksanakan selama kurang lebih 4 bulan dan diikuti oleh seluruh mahasiswa FKIP Universitas Jambi baik program reguler dan reguler mandiri. Hamalik (2009: 171-172) menyatakan bahwa PPL adalah serangkaian kegiatan yang diprogramkan bagi mahasiswa LPTK, yang meliputi baik latihan mengajar maupun latihan di 


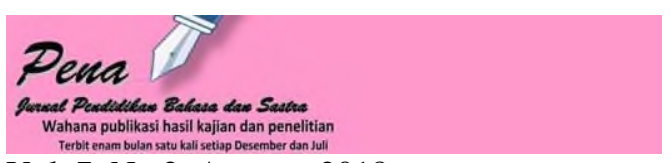

Vol. 7, No.2, Agustus 2018,

P-ISSN: 2089-3973, E-ISSN: 2615-7705

DOI: https://doi.org/10.22437/pena.v7i2.5742

luar mengajar. Kegiatan ini merupakan ajang untuk membentuk dan membina kompetensikompetensi profesional yang disyaratkan oleh pekerjaan guru atau lembaga kependidikan lainnya. Sasaran yang ingin dicapai adalah kepribadian calon pendidik yang memiliki seperangkat pengetahuan, keterampilan, nilai dan sikap, serta pola tingkah laku yang diperlukan bagi profesinya serta cakap dan tepat menggunakannya di dalam menyelenggarakan pendidikan dan pengajaran, baik di sekolah maupun di luar sekolah.

Sebelum berada di lapangan (sekolah) mahasiswa calon guru sebelumnya diberikan pembekalan selama kurang lebih 10 hari untuk mendalami kemampuan dasar mengajar. Materi ini disajikan oleh para pakar dan ahli internal yang berasal dari beberapa prodi FKIP Universitas Jambi. Setelah itu, mahasiswa calon guru melaksanakan kegiatan peer teaching selama beberapa kali penampilan untuk memantapkan cara dan gaya mengajar di kelas nyata nantinya dengan dipandu oleh ahli pembelajaran sesuai dengan disiplin ilmu masing-masing. Tujuan dari pelaksanaan kegiatan ini adalah untuk memantapkan dan membekali mahasiswa calon guru kemampuan mengajar serta menginformasikan realitas kelas praktik pembelajaran.

\section{METODE PENELITIAN}

Model penelitian dan pengembangan yang digunakan dalam penelitian ini yaitu model Dick, Carrey \& Carrey (2009), yaitu: (1) mengidentifikasi tujuan pembelajaran, (2) melakukan analisis pembelajaran dan ketrampilan bawahan, (3) menganalisis pebelajar dan lingkungan, (4) merumuskan tujuan khusus, (5) mengembangkan instrumen penilaian, (6) mengembangkan strategi pembelajaran, (7) mengembangkan dan memilih materi pembelajaran, (8) mendesain, dan (9) melakukan evaluasi formatif. Subjek penelitian dalam penelitian ini yaitu Ahli Teknologi Pendidikan, Teman Sejawat dan peserta didik. Instrumen yang digunakan yaitu lembar angket validasi, lembar tanggapan teman sejawat dan lembar tanggapa peserta didik. 


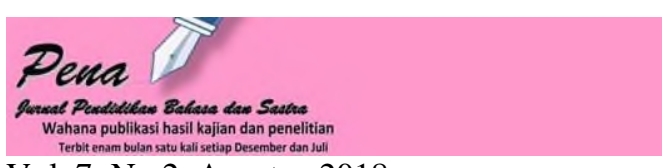

Vol. 7, No.2, Agustus 2018,

P-ISSN: 2089-3973, E-ISSN: 2615-7705

DOI: https://doi.org/10.22437/pena.v7i2.5742

\section{HASIL PENELITIAN}

\section{Data Uji Validasi Ahli}

Uji validasi materi adalah kegiatan penilaian yang dilakukan oleh ahli materi, yang dilihat dalam hal ini yaitu sejauhmana kedalaman materi serta ketepatan isi di dalam modul belajar materi keterampilan mengajar berbasis Problem Based Learning yang dikembangkan.

Skor perolehan pada tahap uji validasi ahli diperoleh skor sebesar 84,62\%. Berdasarkan kriteria kelayakan produk, hasil uji validasi dengan kualifikasi sangat layak. Sehingga produk yang dikembangkan dapat digunakan tanpa revisi. Meskipun demikian, beberapa catatan berupa saran dan komentar dijadikan sebagai landasan untuk dilakukan revisi untuk digunakan pada tahap selanjutnya.

\section{Data Tanggapan Teman Sejawat}

Data tanggapan teman sejawat diperlukan dalam proses pengembangan ini untuk mengetahui kepraktisan produk yang sudah dikembangkan. Informasi dari teman sejawat digunakan sebagai rujukan dalam melakukan revisi produk untuk disesuaikan dengan teori dalam proses pembelajaran melalui pengumpulan angket yang diberikan peneliti pada teman sejawat. Hasil perolehan hasil tanggapan teman sejawat terhadap modul belajar sebesar 91,2 $\%$. Hasil tersebut di konversi berada pada kualifikasi sangat layak. Dengan demkian, produk yang dikembangkan masuk dalan kategori kriteria digunakan tanpa revisi.

\section{Data Tanggapan Mahasiswa}

Tanggapan mahasiswa yaitu data kepraktisan produk juga dikumpulkan melalui penyebaran angket untuk mahasiswa. Angket tanggapan mahasiswa bertujuan untuk mengetahui tanggapan dari mahasiswa terhadap produk yang dikembangkan. Hasil perolehan uji lapangan terbatas melalui tanggapan perserta didik diperoleh hasil dengan presentase ratarata sebesar 75,16\%. Setelah dikonversi, hasil tersebut berada pada tingkat kualifikasi layak. Dengan demikian produk modul belajar yang digunakan berkreteria dapat digunakan namun perlu revisi. Setelah uji coba telah semua dilaksanakan, tahap selanjutnya melakukan revisi produk berdasarkan catatan berupa saran dan komentar yang muncul. Setelah itu, barulah kemudian produk yang sudah direvisi dapat dipergunakan sebagai upaya meningkatkan keterampilan dasar mengajar guru. 


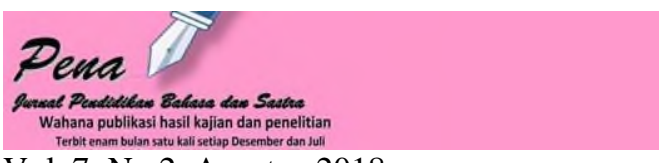

Vol. 7, No.2, Agustus 2018,

P-ISSN: 2089-3973, E-ISSN: 2615-7705

DOI: https://doi.org/10.22437/pena.v7i2.5742

\section{PEMBAHASAN}

Pengembangan Materi keterampilan mengajar berbasis Problem Based Learning untuk meningkatkan kompetensi pedagogik mahasiswa FKIP Universitas Jambi ini bertujuan untuk mengetahui tingkat kelayakan produk pengembangan berupa pengembangan materi Keterampilan Mengajar yang disusun ke dalam sebuah modul belajar. Analisis kelayakan produk modul belajar sudah mendapatkan kualifikasi sangat layak dari hasil uji validasi ahli. Sehingga produk yang dikembangkan dapat digunakan tanpa revisi.

Modul Keterampilan Mengajar Berbasis Problem Based Learning disusun dengan sistematika antara lain: (1) Petunjuk belajar ; (2) Kompetensi yang akan dicapai; (3) Content atau isi materi; (4) Informasi pendukung; (5) Latihan-latihan; (6) Petunjuk kerja; (7) Evaluasi; dan (8) Balikan terhadap hasil evaluasi. Pembelajaran menggunakan modul memungkin sesorang peserta didik belajar lebih cepat dalam menyelesaikan seluruh kompetensi yang diharapkan, tergantung kemampuan dan kecepatan peserta didik dalam belajar.

Skor perolehan yang dari hasil uji validasi ahli mendapat skor presentase sebesar $84,62 \%$. Dengan demikian, skor perolehan yang diperoleh dari hasil uji validasi ahli dinyatakan bahwa produk yang sudah dikembangkan sangat layak untuk digunakan. Kelayakan produk tersebut dapat ditinjau berdasarkan: (a) Tujuan dan Pendekatan; (b) Desain dan Organisasi; (c) Konten Kebahasaan; (d) Metodologi; dan (e) Pertimbangan kepraktisan.

Kelayakan produk yang sudah divalidasi selanjutnya, melakukan uji coba lapangan terbatas yang melibatkan dosen dan peserta didik yang mengontrak mata kuliah Praktik Pengalaman Lapangan (PPL). Kelayakan produk pada uji coba ini meliputi tanggapan teman sejawat dan peserta didik dalam menggunakan modul belajar keterampilan dasar mengajar. Kelayakan modul belajar berdasarkan tanggapan dosen dengan perolehan hasil tanggapan dosen terhadap modul belajar sebesar 91,2 \%. Hasil tersebut di konversi berada pada kualifikasi sangat layak. Dengan demkian, produk yang dikembangkan masuk dalan kategori kriteria digunakan tanpa revisi.

Sedangkan kriteria kelayakan modul belajar berdasarkan tanggapan peserta didik ditinjau berdasarkan: (a) kelayakan isi (konten); (b) kelayakan penyajian; dan (c) kelayakan bahasa. Hasil perolehan uji lapangan terbatas melalui tanggapan perserta didik diperoleh hasil dengan presentase rata-rata sebesar $75,16 \%$. Setelah dikonversi, hasil tersebut berada pada 


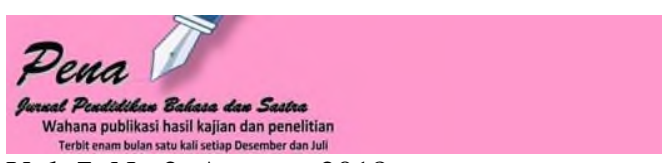

Vol. 7, No.2, Agustus 2018,

P-ISSN: 2089-3973, E-ISSN: 2615-7705

DOI: https://doi.org/10.22437/pena.v7i2.5742

tingkat kualifikasi layak. Dengan demikian produk modul belajar yang digunakan berkreteria dapat digunakan namun perlu revisi.

Hasil Pengembangan Materi Keterampilan Mengajar Berbasis Problem Based Learning Untuk Meningkatkan Kompetensi Pedagogik Mahasiswa FKIP Universitas Jambi telah mengahasilkan modul belajar yang memenuhi karakteristik modul belajar yang baik sesuai dengan pendapat Daryanto (2013:9), yaitu sebagai berikut:

1. Self Intruction, karena modul belajar memuat tujuan pembelajaran yang jelas, dan dapat menggambarkan kompetensi yang akan dicapai, memuat materi pembelajaran yang dikemas dalam unit-unit kegiatan yang kecil dan spesifik, sehingga mudah dipelajari secara tuntas, tersedia contoh dan ilustrasi yang mendukung kejelasan pemaparan materi pembelajaran, terdapat soal-soal latihan, tugas dan sejenisnya yang memungkinkan untuk mengukur penguasaan peserta didik, kontekstual yaitu materi yang disajikan terkait dengan suasana, tugas atau konteks kegiatan dan lingkungan peserta didik, menggunakan bahasa yang sederhana dan komunikatif, terdapat rangkuman materi pembelajaran, terdapat aturan penilaian yang memungkinkan peserta didik dapat melakukan penilaian diri, terdapat informasi tentang rujukan/ pengayaan/ referensi yang mendukung materi yang dimaksud.

2. Self Contained, karena seluruh Materi Keterampilan Mengajar yang dibutuhkan dalam pembelajaran termuat dalam modul belajar tersebut.

3. Stand Alone, karena modul belajar tidak tergantung pada bahan ajar/media lain, tidak harus digunakan bersama-sama dengan bahan ajar/media lain.

4. Adaptive, karena dapat menyesuaikan dengan perkembangan ilmu pengetahuan dan teknologi, secara fleksibel/luwes digunakan diberbagai perangkat keras (hardware).

5. Bersahabat/Akrab (User Friendly) karena setiap instruksi dan paparan informasi yang ditampilkan bersifat membantu dan bersahabat dengan pemakainya, mudah pemakai dalam merespon dan mengakses sesuai dengan keinginan, penggunaan bahasa yang sederhana dan mudah dimengerti, menggunakan istilah yang umum digunakan.

\section{SIMPULAN}

Hasil Pengembangan Materi Keterampilan Mengajar Berbasis Problem Based Learning Untuk Meningkatkan Kompetensi Pedagogik Mahasiswa FKIP Universitas Jambi 


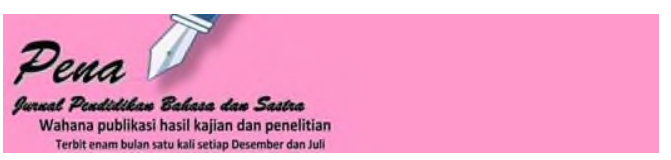

Vol. 7, No.2, Agustus 2018,

P-ISSN: 2089-3973, E-ISSN: 2615-7705

DOI: https://doi.org/10.22437/pena.v7i2.5742

telah mengahasilkan modul belajar yang memenuhi karakteristik modul belajar yang baik dengan kriteria yang baik. Lebih lanjut agar produk pengembangan yang dihasilkan dapat dimanfaatkan untuk kalangan lebih luas dengan penyesuaian terutama penyesuaian pada karakteristik peserta didik sebagai pengguna.

\section{UCAPAN TERIMA KASIH}

Dengan selesainya penulisan artikel hasil laporan penelitian ini penulis mengucapkan terima kasih kepada:

1. Ketua LPPM Universitas Jambi.

2. Dekan FKIP Universitas Jambi.

3. Ketua DP2M FKIP Universitas Jambi.

4. Seluruh pihak yang sudah membantu, baik moril dan materil

\section{DAFTAR RUJUKAN}

Amin, Muhammad., Aunurrahman, M. Thamrin. 2015. Hubungan Kompetensi Pedagogik Dan Kompetensi Kepribadian Dengan Kinerja Guru. Program Magister Administrasi Pendidikan FKIP Universitas Tanjung Pura Pontianak.

Anitah, Sri W, dkk. 2009. Startegi Pembelajaran di SD. Jakarta: Universitas Terbuka.

Arifin, Syamsul dan Adi Kusrianto. 2009. Sukses Menulis Modul belajar \& Referensi. Jakarta: PT Grasindo.

Daryanto. 2013. Menyususn Modul: Bahan Ajar untuk Persiapan Guru dalam Mengajar. Yogyakarta: Gava Media.

Depdiknas. 2008. Panduan Pengembangan Bahan Ajar. Jakarta : Direktorat Pembinaan Sekolah Menengah Atas, Direktorat Jenderal Manajemen Pendidikan Dasar dan Menengah.

Departemen Pendidikan Nasional. 2002. Teknik Belajar dengan Modul. Jakarta: Dirjen PendidikanDasar dan Menengah.

Dick, W., L. Carrey \& J. O. Carrey. 2009. The Systematic Design of Instruction (7th Edition). New Jersey: Pearson Education, Inc.

Hamalik, O. 2009. Pendidikan Guru Berdasarkan Pendekatan Kompetensi. Jakarta: PT Bumi Aksara.

Khofiatun, Sa'dun Akbar, M. Ramli. 2016. Peran Kompetensi Pedagogik Guru Dalam Pembelajaran Tematik Di Sekolah Dasar. Jurnal Pendidikan: Teori, Penelitian, dan 


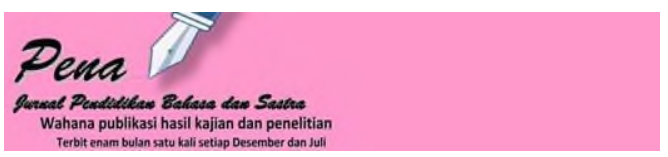

Vol. 7, No.2, Agustus 2018,

P-ISSN: 2089-3973, E-ISSN: 2615-7705

DOI: https://doi.org/10.22437/pena.v7i2.5742

Pengembangan. Volume: 1 Nomor: 5 Bulan Mei Tahun 2016 Halaman: 984-988. EISSN: 2502-471X.

Mulyasa. 2011. Standar Kompetensi dan Sertifikasi Guru. Cet ke-5. Bandung: Remaja Rosdakarya.

Nasution, S. 2000. Berbagi Pendekatan dalam Proses Belajar dan Mengajar. Jakarta: Bumi Aksara.

Najjah, W.S 2014. Pengaruh Nilai Micro Teaching Terhadap Kemampuan Mengajar Praktik Pengalaman Lapangan (PPL) Mahasiswa S1 Program Studi Tadris Biologi Angkatan 2010 Fakultas Ilmu Tarbiyah Dan Keguruan Iain Walisongo Semarang. Skripsi tersedia

http://eprints.walisongo.ac.id/3900/1/103811024_Skripsi_lengkap.pdf

Payong, Marselus R.2011. Sertifikasi Guru. Jakarta: PT Indeks.

Permendiknas Nomor 16 Tahun 2007 tentang Tentang Standar Kualifikasi Akademik dan Kompetensi Guru.

Pupuh Fathurrohman. 2012. Guru Profesional. Bandung: Refika Aditama.

Russel, J.D. 1974. Modular Instructional. A. Guide to the Design, Selection, Utilization and Evaluation of Modular MATERIALS. Minneapolish, Minnesota: Burgerss.

Suryosuroto, B. 1983. Sistem Pengajaran dengan Modul. Yogyakarta: Bina Aksara.

Wulandari, Eka. 2015. Kemampuan Membuka dan Menutup Pelajaran Tematik Berbasis KTSP bagi Guru Sekolah Dasar di Kecamatan Mijen Kota Semarang. Skripsi. Jurusan Pendidikan Guru Sekolah Dasar, Fakultas Ilmu Pendidikan, Universitas Negeri Semarang. 